G.G. Zhemerov, D.S. Krylov

\title{
CONCEPT OF CONSTRUCTION OF POWER CIRCUITS OF A MULTILEVEL MODULAR CONVERTER AND ITS TRANSISTOR MODULES
}

Goal. The goal of the paper is to study the peculiarities of building power circuits of a modular multilevel converter (MMC) of electrical energy for DC transmission lines, to investigate its operating principles and basic characteristics. Methodology. We have applied the theory of electrical circuits and mathematical simulation in Matlab package. Results. A Matlab-model of the MMC power circuit was constructed with shunting of all the shoulders by current sources, which made it possible to check the correctness of the formulas for the characteristics of the proposed circuits. Originality. Variants of power circuits of MMC with shunting of all shoulders of the converter by current sources are offered. The tables of states of HB and FB modules for forward and backward direction of the current of the shoulders are made. Practical value. The use of the proposed structure of the converter power circuit and the algorithms of operation of the power transistor modules will help to determine the scope of their application, will help in the synthesis of the control system and analysis of possible emergency modes of the MMC. References 8, tables 8, figures 9.

Key words: power supply system, multilevel modular converter, transistor module, shoulder currents, Matlab model of threephase MMC, state of valves.

Цель. Целью статьи является исследование особенностей построения силовых цепей многоуровневого модульного преобразователя (ММС) электроэнергии для линий электропередачи постоянного тока, исследование его принципов работы и основных характеристик. Методика. Для проведения исследований использовалась теория электрических цепей, математическое моделирование в пакете Matlab. Результаты. Построена Матlab-модель силовой схемы ММС с иунтированием всех плеч источниками тока, позволивиая проверить корректность формул для характеристик предложенных схем. Научная новизна. Предложены варианты силовых схем ММС с шунтированием всех плеч преобразователя источниками тока. Составлены таблицы состояний НВ и FВ модулей при прямом и обратном направлении токов плеч. Практическое значение. Использование предложсенной структуры силовой схемы преобразователя и алгоритмов работы силовых транзисторных модулей позволит определить сферу их применения, поможет в синтезе системы управления и анализе возможных аварийных режимов ММС. Библ. 8, табл. 8, рис. 9.

Ключевые слова: система электроснабжения, многоуровневый модульный преобразователь, транзисторный модуль, токи плеч, Matlab-модель трехфазного MMC, состояние вентилей.

Introduction. In recent years, powerful industrial semiconductor converters of a new type - modular multilevel converters, first proposed in $[1,2]$ by R. Marquarratt and A. Lesnicar in 2001, 2003, have gained wide industrial application. In numerous publications [3-8], the steady abbreviation $M M C$ is used for these converters. It should be noted the speed with which the MMS was developed, manufactured and put into commercial operation in DC power lines $(H V D C)$. The first $H V D C$ system with $M M C$, developed by Siemens, connected the cities of Pittsburgh and San Francisco in California, USA [7] in November 2010. A DC cable is designed for $400 \mathrm{MW}, \pm 200 \mathrm{kV}$.

Tennet Off-Shore Wind Farm Complex, located in the North Sea near the coast of Germany, implements several $H V D C$ projects for wind power plants using $M M C$. Table 1 shows the characteristics of these projects [8].

In [7] information on the implementation of several other projects using $M M C$, located in Europe and China by Siemens, is presented.

However, despite the active introduction in the world energy sector, in the domestic literature there is practically no information about this type of converter, the principles of its construction, the scope of application.

The goal of the work is to study the peculiarities of building power circuits of a modular multilevel converter (MMC) of electrical energy for DC transmission lines, to investigate its operating principles and basic characteristics.
Table 1

Off-shore wind power plants using $M M C$

\begin{tabular}{|c|c|c|c|c|c|}
\hline $\begin{array}{c}\text { Wind } \\
\text { Power } \\
\text { plant }\end{array}$ & $\begin{array}{c}\text { Power } \\
(\mathrm{MW})\end{array}$ & $\begin{array}{c}\text { Voltage } \\
(\mathrm{kV})\end{array}$ & $\begin{array}{c}\text { Cable } \\
\text { length } \\
(\mathrm{km})\end{array}$ & Performer & $\begin{array}{c}\text { State of } \\
\text { works }\end{array}$ \\
\hline $\begin{array}{c}\text { Helwin } \\
1\end{array}$ & 576 & \pm 250 & 130 & Siemens & $\begin{array}{c}\text { Operating } \\
\text { since 2013 }\end{array}$ \\
\hline $\begin{array}{c}\text { Dolwin } \\
1\end{array}$ & 800 & \pm 640 & 165 & $A B B$ & $\begin{array}{c}\text { Testing in } \\
2013\end{array}$ \\
\hline $\begin{array}{c}\text { Borwin } \\
2\end{array}$ & 800 & \pm 300 & 200 & Siemens & $\begin{array}{c}\text { Testing in } \\
2013\end{array}$ \\
\hline $\begin{array}{c}\text { Sylwin } \\
1\end{array}$ & 864 & \pm 320 & 205 & Siemens & $\begin{array}{c}\text { Operating } \\
\text { since 2014 }\end{array}$ \\
\hline $\begin{array}{c}\text { Dolwin } \\
2\end{array}$ & 900 & \pm 640 & 135 & $A B B$ & $\begin{array}{c}\text { Operating } \\
\text { since 2015 }\end{array}$ \\
\hline $\begin{array}{c}\text { Dolwin } \\
3\end{array}$ & 900 & \pm 320 & 162 & $A B B$ & No data \\
\hline
\end{tabular}

The power circuit and the principle of operation of $\boldsymbol{M M C}$. Fig. 1 shows the power circuits, respectively, of single-phase and three-phase $M M C$. As can be seen from Fig. 1, the power circuit of the converter is powered by two constant voltage sources. Three-phase $M M C$ consists of three single-phase $M M C$, operating independently of each other. Common points of voltage sources and load, $Z_{L}$, are combined. The shoulders of the $M M C$ power circuit, - two shoulders in a single phase and six shoulders in a three phase, - are a series connection of $N$ half-bridge $H B$ modules or full-bridge $F B$ modules, shown in Fig. 1. 


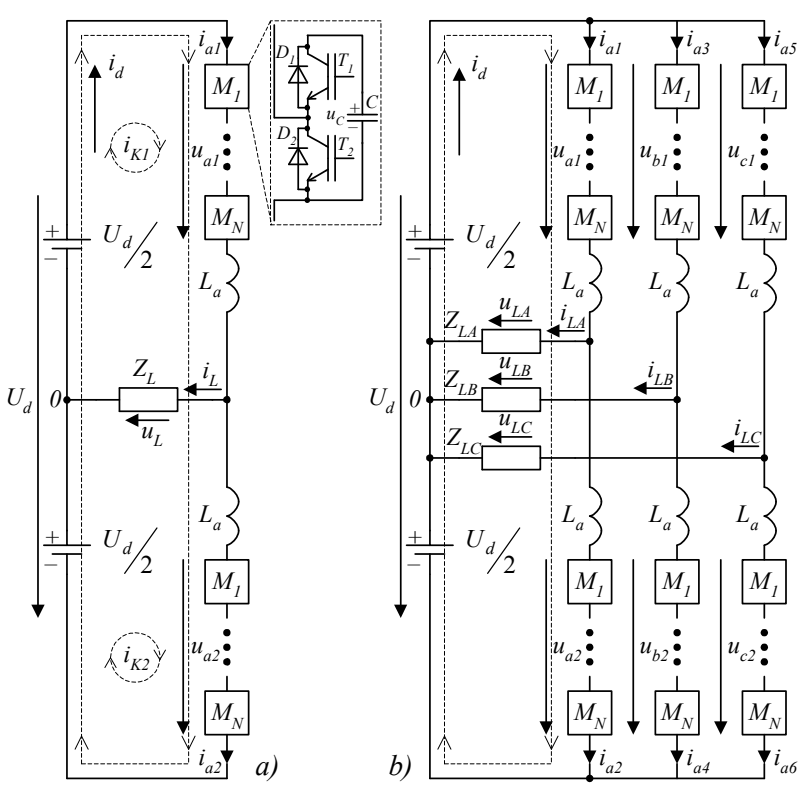

Fig. 1. Power circuits of $M M C$

An equalization reactor $L_{a}$ is included in each shoulder of the circuit. Voltage regulation on the load is carried out by switching on a specified number of modules and a predetermined algorithm of their operation. In the steady-state operation mode of $M M C$, all six keys conduct current at any time, and the total voltage in the closed circuits shown in Fig. 1, $a$ by the dotted line, at zero equalizing current should be zero. Graphs of shoulder voltages are shown in Fig. 2, they correspond to the relations:

$$
\begin{aligned}
& u_{a 1}=\frac{U_{d}}{2}-v \cdot \frac{U_{d}}{2} \cdot \sin \vartheta, \\
& u_{a 2}=\frac{U_{d}}{2}+v \cdot \frac{U_{d}}{2} \cdot \sin \vartheta
\end{aligned}
$$

where $\vartheta=2 \pi f t$ is the dimensionless time; $f$ is the voltage frequency on the converter output; $v$ is the relative load voltage

$$
v=\frac{U_{1 \max }}{U_{d} / 2} .
$$

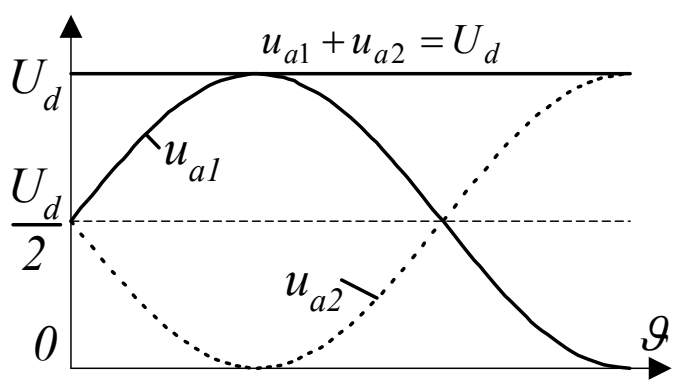

Fig. 2. Voltages of the $M M C$ shoulders

For three-phase $M M C$, the shoulder voltages are determined from the relations:

$$
\begin{aligned}
& u_{b 1}=\frac{U_{d}}{2}-v \cdot \frac{U_{d}}{2} \cdot \sin \left(\vartheta-\frac{2 \pi}{3}\right), \\
& u_{b 2}=\frac{U_{d}}{2}+v \cdot \frac{U_{d}}{2} \cdot \sin \left(\vartheta-\frac{2 \pi}{3}\right),
\end{aligned}
$$

$$
\begin{aligned}
& u_{c 1}=\frac{U_{d}}{2}-v \cdot \frac{U_{d}}{2} \cdot \sin \left(\vartheta-\frac{4 \pi}{3}\right), \\
& u_{c 2}=\frac{U_{d}}{2}+v \cdot \frac{U_{d}}{2} \cdot \sin \left(\vartheta-\frac{4 \pi}{3}\right) .
\end{aligned}
$$

Consider the dependence of the voltage on the load $u_{L}$ on the voltage of the shoulders $u_{a 1}$ and $u_{a 2}$.

For the two closed circuits shown in Fig. 1, $a$ by the dotted line, the following relations are true:

For the first circuit:

$$
\frac{U_{d}}{2}-u_{a 1}-L_{a} \frac{d i_{a 1}}{d t}-u_{L}=0
$$

or

$$
u_{L}=-u_{a 1}-L_{a} \frac{d i_{a 1}}{d t}+\frac{U_{d}}{2} .
$$

For the second circuit:

$$
\frac{U_{d}}{2}-u_{a 2}-L_{a} \frac{d i_{a 1}}{d t}+u_{L}=0
$$

or

$$
u_{L}=u_{a 2}+L_{a} \frac{d i_{a 1}}{d t}-\frac{U_{d}}{2} .
$$

Summing up the left and right sides of equations (10) and (12), we get

$$
2 u_{L}=u_{a 2}-u_{a 1}-L_{a} \frac{d\left(i_{a 1}-i_{a 2}\right)}{d t} .
$$

Taking into account (8), we convert (13):

$$
u_{L}=\frac{u_{a 2}-u_{a 1}}{2}+\frac{L_{a}}{2} \cdot \frac{d i_{L O A D}}{d t},
$$

or

$$
u_{L}=\frac{u_{a 2}-u_{a 1}}{2}+\frac{\omega L_{a}}{2} \cdot \frac{d i_{L O A D}}{d \vartheta},
$$

In relations (14), (15) there is an inequality

$$
I_{L O A D} \cdot \omega \cdot L_{a}<<U_{L \max },
$$

which, under certain conditions, allows us to simplify the relation (15)

$$
u_{L}=\frac{u_{a 2}-u_{a 1}}{2} .
$$

In the circuit of Fig. 1,a

$$
U_{L \max }=v \frac{U_{d}}{2} \text {. }
$$

Assuming that $u_{L}$ is determined by (17), taking into account (1) and (2), we obtain:

$$
\begin{aligned}
u_{L} & =\frac{\frac{U_{d}}{2}+v \frac{U_{d}}{2} \sin \vartheta-\frac{U_{d}}{2}+v \frac{U_{d}}{2} \sin \vartheta}{2}= \\
& =v \frac{U_{d}}{2} \sin \vartheta
\end{aligned} .
$$

Fig. 3 shows the relative position of the voltage curves of the shoulders and the load of phase $a$. The voltages of phases $b$ and $c$ are repeated in the form of the voltage of phase $a$ and are behind it, respectively, at angles of $2 \pi / 3$ and $4 \pi / 3$.

In single-phase $M M C$, shoulder currents have two components - a constant current $I_{d}$ and an alternating sinusoidal current with an amplitude equal to half the 
amplitude of the load current $I_{L \max }$. The dependencies for shoulder currents are:

$$
\begin{aligned}
& i_{a 1}=I_{d}+\frac{1}{2} I_{L \max } \cdot \sin (\vartheta-\varphi), \\
& i_{a 2}=I_{d}-\frac{1}{2} I_{L \max } \cdot \sin (\vartheta-\varphi),
\end{aligned}
$$

where $\varphi$ is the phase angle between voltage and load current.

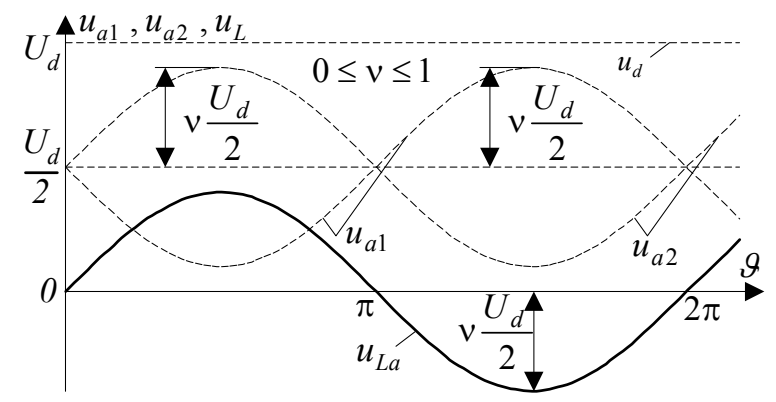

Fig. 3. Graphs of current and voltages of phase $a$

In the three-phase $M M C$, the DC component of the shoulder current will be one third of the current $I_{d}$.

Note that the value of the current $I_{d}$ at $U_{d}=$ const uniquely determines the rate of energy transfer from the source to the load. At the same time, the average value of the total energy in the module capacitors for the period of repetition remains unchanged.

Fig. 4 shows the graphs of voltages and currents of the shoulders and load in the repetition period. From Fig. 4 it follows that the amplitude of the load current must be less than the current $I_{d}$ :

$$
I_{L \max }<I_{d},
$$

and the amplitude of the voltage on the load $U_{L \text { max }}$ must not exceed $U_{d} / 2$ :

$$
U_{L \max }<\frac{U_{d}}{2}
$$

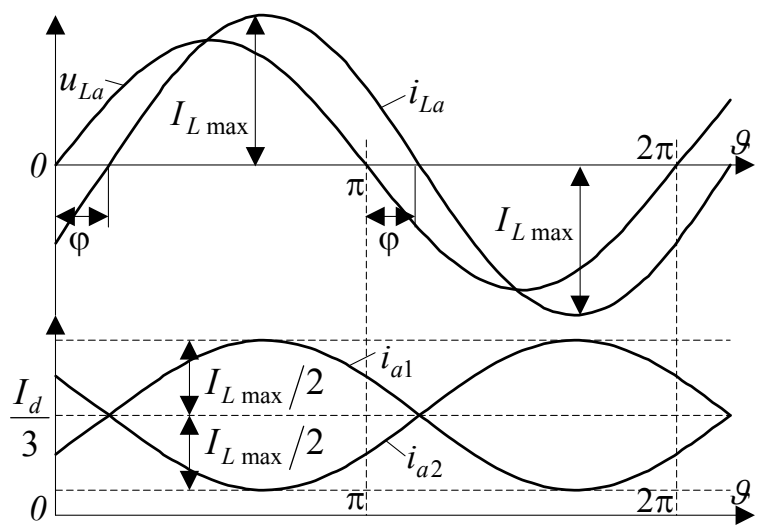

Fig. 4. Graphs of voltages and currents of shoulders and load in the repetition period

At further analysis it is convenient to go to the relative values of voltages and currents.

The basic values of voltages, currents and active power of a three-phase converter:

$$
U_{\text {base }}=U_{d} / 2 \text {, }
$$

$$
\begin{aligned}
& I_{\text {base }}=\frac{2}{3} I_{d}, \\
& P_{\text {base }}=U_{d} \cdot I_{d} .
\end{aligned}
$$

From relations (3), (24) we find the relative value of the amplitude of the sinusoid voltage on the load:

$$
U_{L \text { max }}=\frac{U_{L \max }}{U_{\text {base }}}=\frac{2 U_{L \max }}{U_{d}}=v,
$$

and taking into account (25) - the relative value of the amplitude of the current phase of the load:

$$
I_{L \text { max }}=\frac{3}{2} \frac{I_{L \max }}{I_{d}}=m .
$$

Assuming that there are no losses in the $M M C$, we can write a relation for the average active power at the input and output of the three-phase $M M C$ :

$$
U_{d} \cdot I_{d}=\frac{3}{2} I_{L \max } U_{L \max } \cos \varphi .
$$

Substituting in (29) $U_{L \max }$ from (27) and $I_{L \max }$ from (28), we obtain:

$$
2=v \cdot m \cdot \cos \varphi .
$$

Relation (30) connects the relative values of voltage $v$ and the amplitude of the load current $m$.

In [3] it is recommended to set the range of change of $v$ within

$$
0 \leq|v| \leq 1,
$$

at using the $H B$-modules and within

at using the $F B$-modules.

$$
0 \leq v \leq \sqrt{2},
$$

This recommendation can be explained by the assumption of flattening of the output voltage curve in the amplitude region. The sign of the modulus of $v$ in relations (31), (32) does not make sense, since, in accordance with (27), the quantity is always positive.

The recommended value of the parameter $m[3]$ :

$$
|m| \geq 2
$$

for both types of modules.

Possible theoretical values of the parameter $m$, calculated as a function of the parameters $v$ and $\cos \varphi_{2}$ and by expression (30), are given in Table 2 .

Mathematical modelling. In order to verify the results obtained above, in the MatLab/Simulink software environment a mathematical model of a three-phase $M M C$, corresponding in its structure to Fig. 1, $b$, was created. The view of the model is shown in Fig. 5.

The model consists of a power source $U_{d}$, a capacitive divider $C_{d 1}-C_{d 2}$, to the midpoint of which a common output of a three-phase active-inductive load $L_{-} A, L_{-} B, L_{-} C$, connected to a star, is connected. The shoulder voltages are set by adjustable AC voltage sources $U_{a l}-U_{a 2}, U_{b 1}-U_{b 2}, U_{c 1}-U_{c 2}$ for each of the three phases. The shoulder current shapes are set by adjustable sources $I_{a 1}-I_{a 2}, I_{b 1}-I_{b 2}, I_{c 1}-I_{c 2}$ with elements connected in parallel with them that simulate the active and inductive resistances of the shoulders of $M M C$. The Invertor block generates the control task for the elements of the circuit. Numerous oscilloscopes and digital displays allow to control all the parameters of the model operation. 
Table 2

Parameter $m$ values as a function of parameters $v, \cos \varphi_{2}$

\begin{tabular}{|c|c|c|c|c|c|c|c|c|c|c|}
\hline $\cos \varphi_{2}$ & 1.0 & 0.9 & 0.8 & 0.7 & 0.6 & 0.5 & 0.4 & 0.3 & 0.2 & 0.1 \\
\hline & & & & & & & & & & \\
\hline 1.0 & 2.00 & 2.22 & 2.50 & 2.86 & 3.33 & 4.00 & 5.00 & 6.67 & 10.00 & 20.00 \\
\hline 0.9 & 2.22 & 2.47 & 2.78 & 3.17 & 3.70 & 4.44 & 5.56 & 7.41 & 11.11 & 22.22 \\
\hline 0.8 & 2.50 & 2.78 & 3.13 & 3.57 & 4.17 & 5.00 & 6.25 & 7.14 & 12.50 & 25.00 \\
\hline 0.7 & 2.86 & 3.17 & 3.57 & 4.08 & 4.76 & 5.71 & 7.14 & 9.52 & 14.29 & 28.57 \\
\hline 0.6 & 3.33 & 3.70 & 4.17 & 4.76 & 5.56 & 6.67 & 8.33 & 11.11 & 16.67 & 33.33 \\
\hline 0.5 & 4.00 & 4.44 & 5.00 & 5.71 & 6.67 & 8.00 & 10.00 & 13.33 & 20.00 & 40.00 \\
\hline 0.4 & 5.00 & 5.56 & 6.25 & 7.14 & 8.33 & 10.00 & 12.50 & 16.67 & 25.00 & 50.00 \\
\hline 0.3 & 6.67 & 7.41 & 7.14 & 9.52 & 11.11 & 13.33 & 16.67 & 22.22 & 33.33 & 66.67 \\
\hline 0.2 & 10.00 & 11.11 & 12.50 & 14.29 & 16.67 & 20.00 & 25.00 & 33.33 & 50.00 & 100.0 \\
\hline 0.1 & 20.00 & 22.22 & 25.00 & 28.57 & 33.33 & 40.00 & 50.00 & 66.67 & 100.0 & 200.0 \\
\hline
\end{tabular}

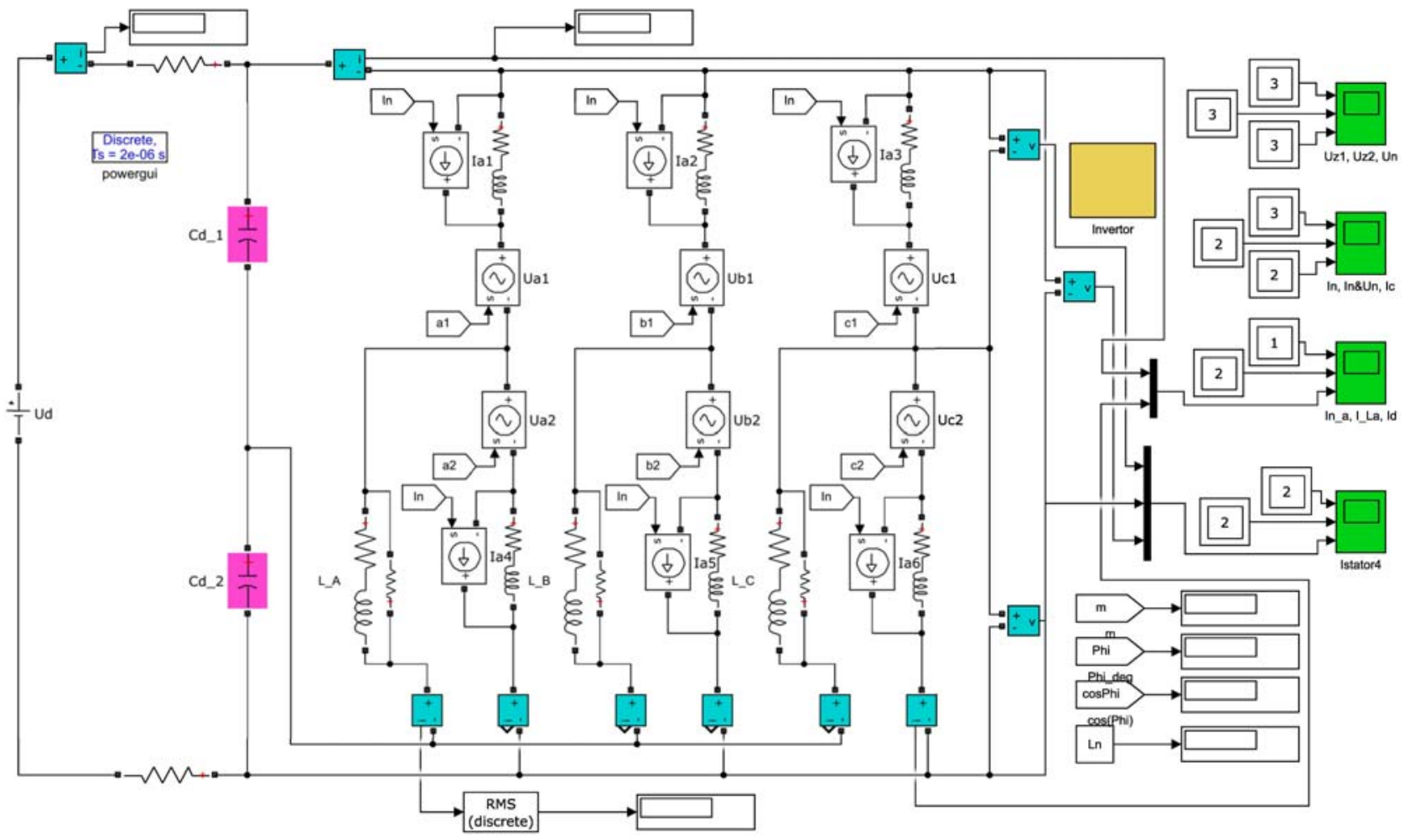

Fig. 5. MatLab model of the three-phase $M M C$

The current and voltage sources are controlled in the model in exact accordance with the $M M C$ algorithm described above. This concept of building a model allows to check the validity of previously made assumptions about the relationship of the main parameters in the operation of the circuit without using models of specific power modules and building a complex system of their control and autoregulation.

During receipt of machine diagrams and dependencies, the following values were taken in the model: the average value of the supply voltage and input current, respectively, $U_{d}=1000 \mathrm{~V}, I_{d}=1000 \mathrm{~A}$; active and inductive resistance of the shoulder $1 \mathrm{~m} \Omega$ and $10 \mu \mathrm{H}$; active load resistance $0.632 \Omega$; capacitance of the divider capacitor $5 \mathrm{mF}$.

Fig. 6 shows machine diagrams of the voltage of the power source $U_{d}$ and the voltage of the shoulders of the phase $c$ for the operation mode $v=1$, which fully corresponds to the theoretical graphs shown in Fig. 2.

Fig. 7 shows machine diagrams of the load voltage of phase $c$ and the voltages forming it for the operation mode $v=0.8$, which fully corresponds to the theoretical graphs shown in Fig. 3.

Figure 8 shows machine diagrams of the current of load and phase $c$ shoulders for the operation mode $v=0.8$. Comparison of Fig. 8 and Fig. 4 makes it possible to verify the validity of the previously accepted theoretical premises.

Also, the model of Fig. 5 allowed to check the $M M C$ operation with various combinations of parameters $m, v$ and $\cos \varphi_{2}$, confirming the validity of the values given in Table 2 with an accuracy of two decimal places.

Characteristics of power modules. The use of a concrete type of power transistor module does not affect the overall concept of $M M C$ operation, however, it affects the features of building the control system and 


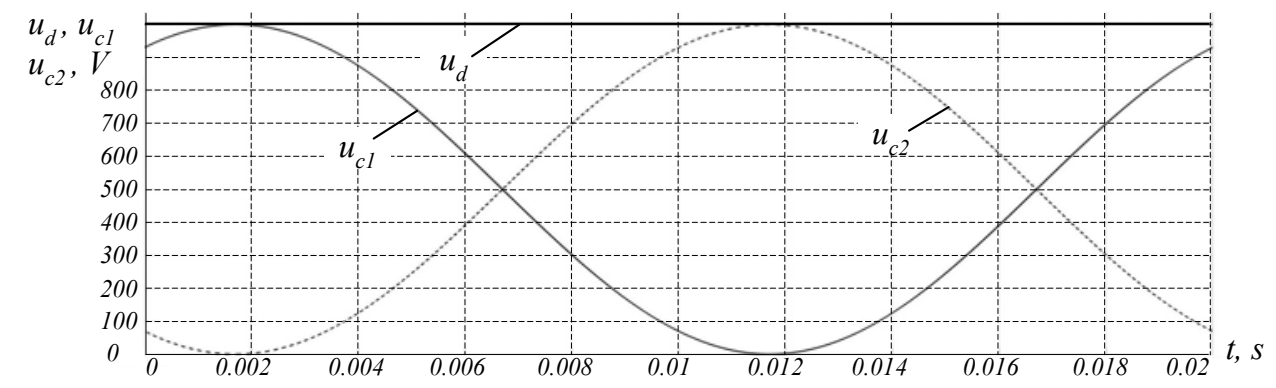

Fig. 6. Voltage of the phase $c$ shoulders

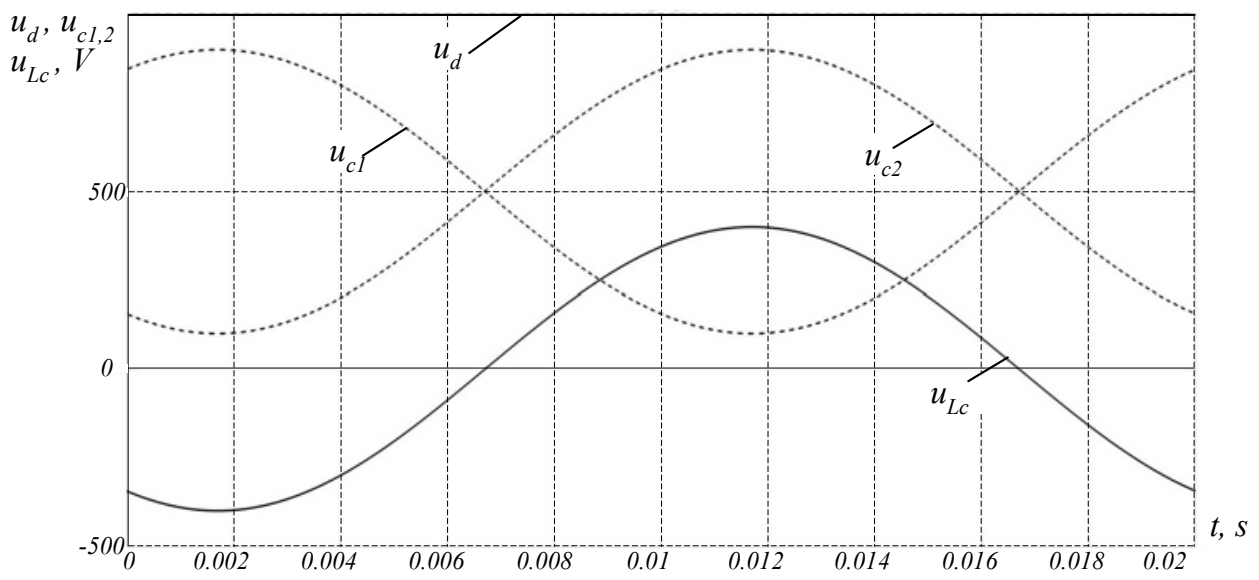

Fig. 7. Voltage of the phase $c$ load

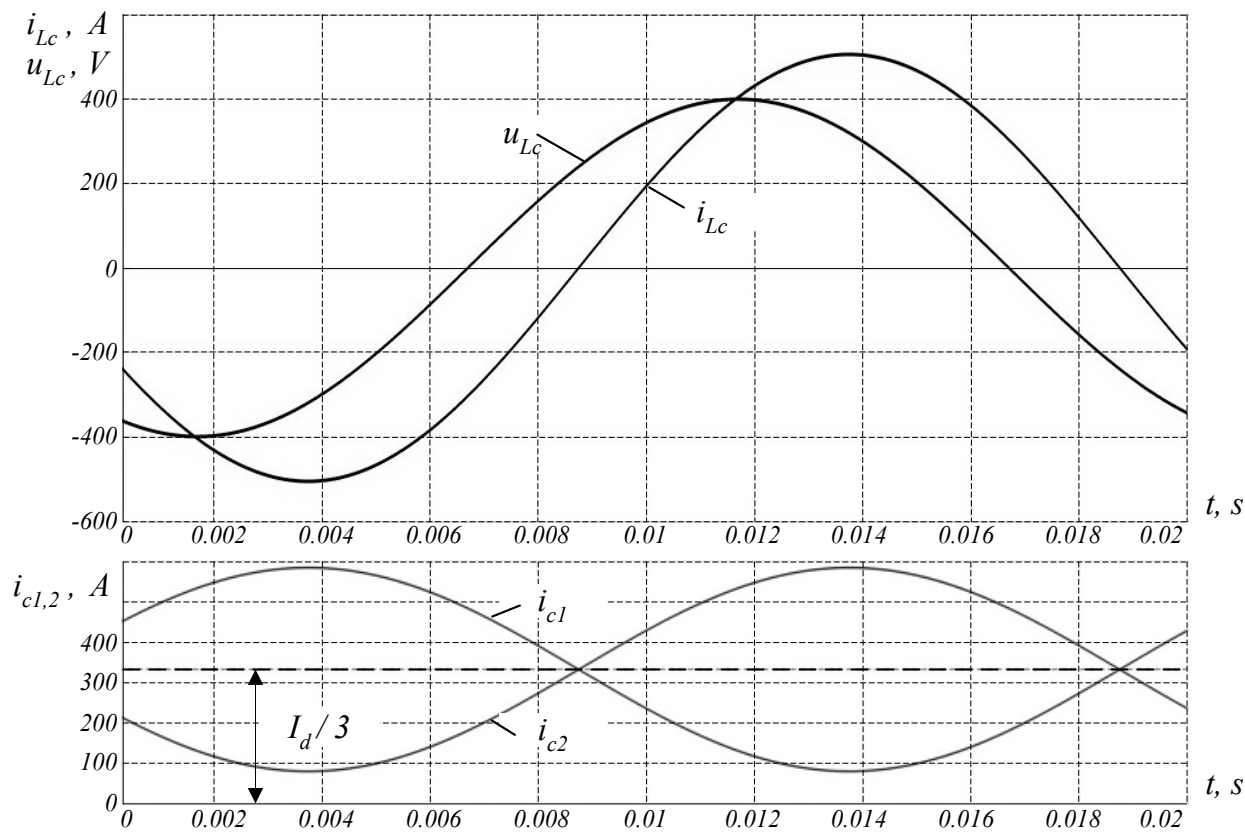

Fig. 8. Current of the phase $c$ load and shoulders

autoregulation and also determines the possible emergency modes in the operation of the circuit. Therefore, we consider their operation in more detail.

a) Half-bridge $H B$ module. The diagram of the halfbridge $H B$ module is shown in Fig.9,a. The current through the module from the power supply can be either positive (the direction of the positive current is shown in Fig. $9, a$ ) or negative. The voltage on the capacitor $C$ is always positive, so when the module is operating, the transistors $T 1$ and $T 2$ cannot be opened at the same time.
With this in mind, there are three possible combinations of open state transistors for each direction of current $i$ :

- both transistors are closed;

- transistor $T 1$ is on, transistor T2 is locked;

- transistor $T 2$ is on, transistor $T 1$ is locked.

Consider the path of current flow, the voltage on the capacitor and the value of the voltage at the input of the module corresponding to the above combinations for positive and negative currents, summarizing the result in Table 3, 4 . 


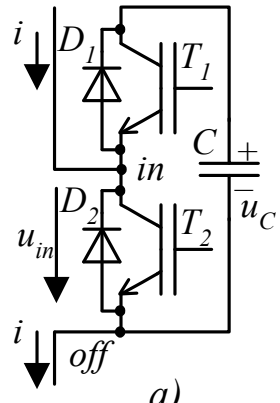

a)

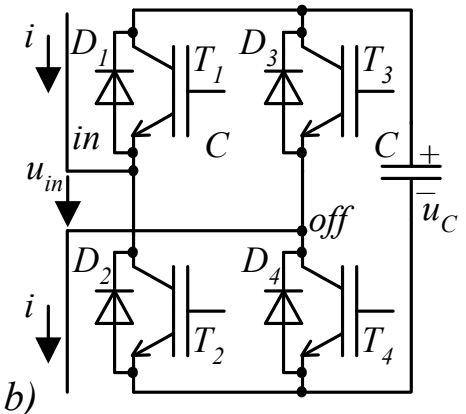

b)

Fig. 9. Circuits of $M M C$ power modules

Table 3

Voltage at the input and at the capacitor of the $H B$ module at positive current $i>0$

\begin{tabular}{|c|c|c|c|c|}
\hline $\begin{array}{c}\text { Combination } \\
\text { No. }\end{array}$ & $\begin{array}{c}\text { Transistors } \\
\text { on }\end{array}$ & $\begin{array}{c}\text { Current } \\
\text { path }\end{array}$ & $\begin{array}{c}\text { Capacitor } \\
\text { voltage }\end{array}$ & $\begin{array}{c}\text { Voltage at } \\
\text { the module } \\
\text { input }\end{array}$ \\
\hline 1.1 & - & $\begin{array}{r}\text { in, D1, } \\
C, \text { off }\end{array}$ & charge & $u_{\text {in }}=u_{C}$ \\
\hline 1.2 & $T 1$ & $\begin{array}{c}\text { in, } D 1, \\
C, \text { off }\end{array}$ & charge & $u_{\text {in }}=u_{C}$ \\
\hline 1.3 & $T 2$ & $\begin{array}{c}\text { in, } T 1, \\
\text { off }\end{array}$ & $\begin{array}{c}\text { does not } \\
\text { change }\end{array}$ & $u_{\text {in }}=0$ \\
\hline
\end{tabular}

Table 4

Voltage at the input and at the capacitor of the $H B$ module at negative current $i<0$

\begin{tabular}{|c|c|c|c|c|}
\hline $\begin{array}{c}\text { Combination } \\
\text { No. }\end{array}$ & $\begin{array}{c}\text { Transistors } \\
\text { on }\end{array}$ & $\begin{array}{c}\text { Current } \\
\text { path }\end{array}$ & $\begin{array}{c}\text { Capacitor } \\
\text { voltage }\end{array}$ & $\begin{array}{c}\text { Voltage at } \\
\text { the module } \\
\text { input }\end{array}$ \\
\hline 2.1 & - & $\begin{array}{c}\text { off, } D 2, \\
\text { in }\end{array}$ & $\begin{array}{c}\text { does not } \\
\text { change }\end{array}$ & $u_{\text {in }}=u_{C}$ \\
\hline 2.2 & $T 1$ & $\begin{array}{c}\text { off, } C, \\
\text { T1, in }\end{array}$ & discharge & $u_{\text {in }}=u_{C}$ \\
\hline 2.3 & $T 2$ & $\begin{array}{c}\text { off, } D 2, \\
\text { in }\end{array}$ & $\begin{array}{c}\text { does not } \\
\text { change }\end{array}$ & $u_{\text {in }}=0$ \\
\hline
\end{tabular}

From the analysis of Table 3, 4 it follows that the capacitor can be charged only with positive current of the module, and it can be discharged only with negative current of the module. Moreover, there are two combinations that ensure the charge of the capacitor and only one combination corresponding to the discharge.

b) Full-bridge FB module.

In the circuit of the bridge module shown in Fig. 9, $b$, pairs of transistors $T 1, T 2$ and $T 3, T 4$ cannot be simultaneously on. Therefore, there are nine possible combinations of on transistors for each of the two directions of current $i$.

- all transistors are locked;

- a pair of transistors $T 1, T 2$ is on;

- a pair of transistors $T 2, T 3$ is on;

- transistors $T 1, T 3$ are on;

- transistors $T 2, T 4$ are on;

- transistor $T 1$ is on, the rest are closed;

- transistor $T 2$ is on, the rest are closed;

- transistor T3 is on, the rest are closed;

- transistor T4 is on, the rest are closed.

Consider the operation of the circuit at a positive current $(i>0)$. The result of the analysis is summarized in Table 5 .
In accordance with Table 5 , in the case of $i>0$, only one combination of switching on transistors ensures the discharge of a capacitor at $u_{i n}=-u_{C}$. Four combinations provide the charge of the capacitor, another four - the constant voltage on the capacitor.

Table 5

Voltage at the input and at the capacitor of the $F B$ module at positive current $i>0$

\begin{tabular}{|c|c|c|c|c|}
\hline $\begin{array}{c}\text { Combination } \\
\text { No. }\end{array}$ & $\begin{array}{c}\text { Transistors } \\
\text { on }\end{array}$ & $\begin{array}{c}\text { Current } \\
\text { path }\end{array}$ & $\begin{array}{l}\text { Capacitor } \\
\text { voltage }\end{array}$ & $\begin{array}{l}\text { Voltage at } \\
\text { the module } \\
\text { input }\end{array}$ \\
\hline 3.1 & - & \begin{tabular}{|c|} 
in, D1, \\
C. D4.off
\end{tabular} & charge & $u_{i n}=u_{C}$ \\
\hline 3.2 & $T 1, T 4$ & $\begin{array}{c}\text { in, D1, } \\
C, D 4, \text { off }\end{array}$ & charge & $u_{i n}=u_{C}$ \\
\hline 3.3 & $T 2, T 3$ & $\begin{array}{c}\text { in, } T 2, C \text {, } \\
\text { T3, off }\end{array}$ & discharge & $u_{i n}=-u_{C}$ \\
\hline 3.4 & $T 1, T 3$ & $\begin{array}{c}\text { in, D1, } \\
\text { T3, off }\end{array}$ & $\begin{array}{l}\text { does not } \\
\text { change }\end{array}$ & $u_{i n}=0$ \\
\hline 3.5 & $T 2, T 4$ & $\begin{array}{l}\text { in, T2, } \\
\text { D4, off }\end{array}$ & $\begin{array}{l}\text { does not } \\
\text { change }\end{array}$ & $u_{\text {in }}=0$ \\
\hline 3.6 & $T 1$ & $\begin{array}{l}\text { in, } D 1 \text {, } \\
C, D 4 \text {, } \\
\text { off }\end{array}$ & charge & $u_{i n}=u_{C}$ \\
\hline 3.7 & $T 2$ & $\begin{array}{l}\text { in, T2, } \\
D 4, \text { off }\end{array}$ & $\begin{array}{l}\text { does not } \\
\text { change }\end{array}$ & $u_{\text {in }}=0$ \\
\hline 3.8 & $T 3$ & $\begin{array}{l}\text { in, D1, } \\
\text { T3, off }\end{array}$ & $\begin{array}{l}\text { does not } \\
\text { change }\end{array}$ & $u_{i n}=0$ \\
\hline 3.9 & T4 & $\begin{array}{l}\text { in, D1, } \\
C, D 4 \text {, } \\
\text { off }\end{array}$ & charge & $u_{i n}=u_{C}$ \\
\hline
\end{tabular}

Consider the case when $i<0$. From Table 6 it follows that at $i<0$, only one combination ensures the discharge of the capacitor at $u_{i n}=+u_{C}$, four combinations ensure the charge of the capacitor at $u_{i n}=-u_{C}$, four more combinations ensure that the voltage on the capacitor remains constant at $u_{i n}=0$. The analysis data are given in Table 7, 8 .

Table 6

Voltage at the input and at the capacitor of the $F B$ module at negative current $i<0$

\begin{tabular}{|c|c|c|c|c|}
\hline $\begin{array}{c}\text { Combination } \\
\text { No. }\end{array}$ & $\begin{array}{c}\text { Transistors } \\
\text { on }\end{array}$ & $\begin{array}{c}\text { Current } \\
\text { path }\end{array}$ & $\begin{array}{c}\text { Capacitor } \\
\text { voltage }\end{array}$ & $\begin{array}{c}\text { Voltage at } \\
\text { the module } \\
\text { input }\end{array}$ \\
\hline 4.1 & - & $\begin{array}{c}\text { off, } D 3, \\
C, D 2, \text { in }\end{array}$ & charge & $u_{\text {in }}=-u_{C}$ \\
\hline 4.2 & $T 1, T 4$ & $\begin{array}{c}\text { off, } T 4, \\
C, T 1, \text { in }\end{array}$ & discharge & $u_{\text {in }}=u_{C}$ \\
\hline 4.3 & $T 2, T 3$ & $\begin{array}{c}\text { off, } D 3, \\
C, T 2, \text { in }\end{array}$ & charge & $u_{\text {in }}=-u_{C}$ \\
\hline 4.4 & $T 1, T 3$ & $\begin{array}{c}\text { off, } D 3, \\
T 1, \text { in }\end{array}$ & $\begin{array}{c}\text { does not } \\
\text { change }\end{array}$ & $u_{\text {in }}=0$ \\
\hline 4.5 & $T 2, T 4$ & $\begin{array}{c}\text { off, } T 4, \\
D 2, \text { in }\end{array}$ & $\begin{array}{c}\text { does not } \\
\text { change }\end{array}$ & $u_{\text {in }}=0$ \\
\hline 4.6 & $T 1$ & $\begin{array}{c}\text { off, } D 3, \\
T 1, \text { in }\end{array}$ & $\begin{array}{c}\text { does not } \\
\text { change }\end{array}$ & $u_{\text {in }}=0$ \\
\hline 4.7 & $T 2$ & $\begin{array}{c}\text { off, } D 3, \\
C, D 2, \text { in }\end{array}$ & charge & $u_{\text {in }}=-u_{C}$ \\
\hline 4.8 & $T 3$ & $\begin{array}{c}\text { off, } D 3, \\
C, D 2, \text { in }\end{array}$ & charge & $u_{\text {in }}=-u_{C}$ \\
\hline 4.9 & $T 4$ & $\begin{array}{c}\text { off, } T 4, \\
D 2, \text { in }\end{array}$ & $\begin{array}{c}\text { does not } \\
\text { change }\end{array}$ & $u_{\text {in }}=0$ \\
\hline
\end{tabular}


The data of Table 3-8 can be used in the synthesis of the control system and for the analysis of possible emergency conditions in the $M M C$ modules.

Since the current $i$ is generated by the current source, the open circuit inside the module is most dangerous. In the $H B$ modules (Fig. 9,a), when the $T 2$ transistor is closed, an open circuit in the current $i$ flow circuit will cause an arc, overvoltage on the $T 2$ transistor and the $D 2$ diode with subsequent breakdown of one of them.

Table 7

Numbers of options for the operation mode of the $F B$ module at $i>0$

\begin{tabular}{|c|c|c|c|c|}
\hline \multicolumn{2}{|c|}{ Voltage sign at the output $u_{\text {in }}$} & + & - & 0 \\
\hline \multirow{4}{*}{$\begin{array}{c}\text { Voltage on the } \\
\text { capacitor }\end{array}$} & $\begin{array}{c}\text { charge } \\
\text { (increased) }\end{array}$ & $\begin{array}{c}3.1,3.2, \\
3.6,3.9\end{array}$ & no & no \\
\cline { 2 - 5 } & $\begin{array}{c}\text { discharge } \\
\text { (decreases) }\end{array}$ & no & 3.3 & no \\
\cline { 2 - 5 } & $\begin{array}{c}\text { does not } \\
\text { change }\end{array}$ & no & no & $\begin{array}{c}3.4,3.5, \\
3.7,3.8\end{array}$ \\
\hline
\end{tabular}

Table 8

Numbers of options for the operation mode of the $F B$ module

\begin{tabular}{|c|c|c|c|c|}
\hline \multicolumn{2}{|c|}{ Voltage sign at the output $u_{\text {in }}$} & + & - & 0 \\
\hline \multirow{3}{*}{$\begin{array}{l}\text { Voltage on the } \\
\text { capacitor }\end{array}$} & $\begin{array}{c}\text { charge } \\
\text { (increased) }\end{array}$ & no & $\begin{array}{r}4.1,4.3, \\
4.7,4.8\end{array}$ & No \\
\hline & $\begin{array}{c}\text { discharge } \\
\text { (decreases) }\end{array}$ & 4.2 & no & no \\
\hline & $\begin{array}{c}\text { does not } \\
\text { change }\end{array}$ & no & no & $\begin{array}{l}4.4,4.5 \text {, } \\
4.6,4.9\end{array}$ \\
\hline
\end{tabular}

When transistors $T 1, T 2$ are simultaneously on, capacitor $C$ is discharged to them. The discharge current can lead to burnout of the conductors (tracks) inside the transistors, the occurrence of an arc and the emission of plasma.

Conclusions.

1. The concept of construction of a multi-level modular converter $(M M C)$ for DC transmission lines in power engineering and powerful frequency-controlled electric drive is considered.

2. Mathematical modeling in MatLab/Simulink software environment confirmed the validity of the considered $M M C$ operation algorithm and the correctness of mathematical relationships describing the processes in the steady state operation.

3. The characteristics of the full set of combinations of states of transistors of half-bridge $H B$ (six states) and fullbridge $F B$ (eighteen states) power modules are given, which should be considered when synthesizing a control system and analyzing emergency modes.

\section{REFERENCES}

1. Marquardt R. Stramrichterchaltungen mit verteilten energiespeichern. Patent German, DE20 122923V1, 2001. (Ger).

2. Lesnicar A., Marquardt R. An innovative modular multilevel converter topology suitable for a wide power range. 2003 IEEE Bologna Power Tech Conference Proceedings, 2003, vol.3, p. 6. doi: 10.1109/PTC.2003.1304403.

3. Hagiwara M., Akagi H. PWM control and experiment of modular multilevel converters. 2008 IEEE Power Electronics Specialists Conference, 2008, pp. 154-161. doi: 10.1109/PESC.2008.4591917.

4. Alstom. HVDC MaxSine. Available at: http://www.alstom.com/grid/products-andservices/engineeredenergy-solutions/hvdc-transmissionsystems/HVDC-MaxSine (accessed 22 August 2013).

5. $A B B$. HVDC Light Gen. 4. Available at: www.new.abb.com/systems/hvdc (accessed 12 August 2013).

6. EPRI. HVDC Flexible. Available at: www.epri.sgec.com.cn/prgc/english/Product Solution/HVDC Flexible (accessed 20 July 2013).

7. SIEMENS. SINAMICSSM120. Available at: http://www.industry.siemens.com/drives/global/en/converter/mv drives/sinamics-sm120-cm (accessed 20 June 2013).

8. Perez M.A., Bernet S., Rodriguez J., Kouro S., Lizana R. Circuit Topologies, Modeling, Control Schemes, and Applications of Modular Multilevel Converters. IEEE Transactions on Power Electronics, 2015, vol.30, no.1, pp. 417. doi: 10.1109/tpel.2014.2310127.

\section{Received 03.09.2018}

G.G. Zhemerov ${ }^{1}$, Doctor of Technical Science, Professor,

D.S. Krylov ${ }^{1}$, Candidate of Technical Science, Associate

Professor,

${ }^{1}$ National Technical University «Kharkiv Polytechnic Institute», 2, Kyrpychova Str., Kharkiv, 61002, Ukraine,

phone +380 577076312 ,

e-mail: zhemerov@gmail.com

\section{How to cite this article:}

Zhemerov G.G., Krylov D.S. Concept of construction of power circuits of a multilevel modular converter and its transistor modules. Electrical engineering \& electromechanics, 2018, no.6, pp. 26-32. doi: 10.20998/2074272X.2018.6.03. 